\title{
IMPLEMENTASI REGULASI TENTANG SURVEYOR KADASTER BERLISENSI DALAM PERCEPATAN PENDAFTARANTANAH DI KANTOR WILAYAH BADAN PERTANAHAN PROVINSI SUMATERA UTARA Eko Budi Wahyono*
}

\begin{abstract}
This research aim to understand the implementation of the regulation of licensed cadaster surveyor in The Regional Office of National Land Agency of the North Sumatera Province on the acceleration of land registration. The research using Qualitative method by describing the results of observation, interview and data of the implementation of accelerated land registration, specifically on the collectors of physical data (PULDASIK - Pengumpul Data Fisik) of the licensed cadastral surveyor, referring to the Regulation of The Minister of Agrarian Affairs and Spatial Planning/Head of National Land Agency Republic of Indonesia Nr. 33 year 2016 and the Regulation of The Minister of Agrarian Affairs and Spatial Planning/Head of National Land Agency Nr. 11 year 2017. The results show that: the implementation of the regulation of Licensed Cadastral Surveyor has not been fully implemented, caused by the limitation of: the number of KJSKB and SKB; ASK graduated from DI PPK-STPN prefer to do apprenticeship so they did not interested in joining KJSKB, and the limitation of financial capability of the KJSKB/SKB. The implementation of the regulation of Licensed Cadastral Surveyor also inhibited by the requirements mentioned on the regulation itself. Moreover, the competency and Quality of the SKB is noticed as above the standard, and have unprofessional work ethic. It is recommended to increase the acceptance of Licensed Cadastral Surveyor, and those who already passed the test should forming KISKB and improve their professionalism by aceuiring certificate of competence when they follow the examination to obtain the license.
\end{abstract}

Keywords: Regulation, Licensed Cadastral Surveyor, Acceleration of Land Registration.

Intisari: Penelitian ini bertujuan untuk mengetahui implementasi regulasi tentang Surveyor Kadaster Berlisensi di Kantor Wilayah Badan Pertanahan Nasional Provinsi Sumatera Utara dalam percepatan pendaftaran tanah. Metode penelitian menggunakan metode kualitatif dengan dideskriptifkan berdasarkan pengamatan, interview, dan data pelaksanaan percepatan pendaftaran tanah khusus pengumpul data fisik (PULDASIK) Surveyor Kadaster Berlisensi dengan berpedoman pada Peraturan Menteri Agraria dan Tata Ruang/Kepala Badan Pertanahan Nasional Republik Indonesia Nomor 33 Tahun 2016 dan Peraturan Menteri Agraria dan Tata Ruang/Kepala Badan Pertanahan Nasional Republik Indonesia Nomor II Tahun 2017. Diperoleh hasil bahwa implementasi regulasi tentang Surveyor Kadaster Berlisensi belum dijalankan sepenuhnya. Hal ini disebabkan oleh keterbatasan jumlah KJSKB dan SKB, ASK lulusan DI PPK-STPN lebih menyukai magang sehingga tidak mau bergabung dengan KJSKB dan keterbatasan modal keuangan yang dimiliki KJSKB/SKB. Pelaksanakan regulasi Surveyor Kadaster Berlisensi juga terhambat oleh persyaratan yang ada di dalam regulasi Surveyor Kadaster Berlisensi, kualitas kompetensi SKB rendah, serta sikap kerja tidak profesional. Maka untuk itu direkomendasikan meningkatkan jumlah penerimaan Surveyor Kadaster Berlisensi dan yang telah lulus ujian lisensi untuk segera membentuk KJSKB dan meningkatkan profesionalisme Surveyor Kadaster Berlisensi dengan melengkapi sertipikat kompetensi saat ujian memperoleh lisensi.

Kata Kunci: Regulasi, Surveyor Kadaster Berlisensi, Percepatan Pendaftaran Tanah.

\section{A. Pendahuluan}

Menurut Peraturan Menteri Negara Agraria dan Tata Ruang/Kepala Badan Pertanahan Nasional Republik Indonesia Nomor 12 Tahun 2017 tentang Percepatan Pendaftaran Tanah Sistematis Lengkap

* Dosen STPN, email: ebudiw65@yahoo.co.id disebutkan bahwa dalam rangka memberikan jaminan kepastian hukum dan perlindungan hukum hak atas tanah rakyat secara adil dan merata serta mendorong pertumbuhan ekonomi negara, Kementerian Agraria dan Tata Ruang/ Badan Pertanahan Nasional (Kementerian ATR/ BPN) melaksanakan program percepatan 
pendaftaran tanah lengkap di seluruh wilayah Republik Indonesia. Target percepatan pendaftaran tanah sistematik lengkap di seluruh Indonesia pada tahun 2017 sebanyak 5 juta bidang tanah, tahun 2018 sebanyak 7 juta bidang tanah, dan tahun 2019 sebanyak 9 juta bidang tanah. Diharapkan pada tahun 2025 semua bidang tanah di wilayah Republik Indonesia telah terdaftar.

Dalam pelaksanaan percepatan pendaftaran tanah sistematik lengkap di seluruh wilayah Indonesia ini, diperlukan daya dukung yang luar biasa terkait aspek sumber daya manusia, infrastruktur pertanahan, maupun regulasi pelaksanaannya. Berdasarkan penelitian dari Pusat Penelitian dan Pengembangan Kementerian ATR/BPN tahun 2015 diperoleh data jumlah bidang tanah di Indonesia sejumlah 90.622.503 bidang dengan jumlah bidang tanah yang telah terdaftar 35.789 .766 bidang dan yang belum terdaftar 54.832 .737 bidang. Terdapat $61 \%$ bidang tanah belum terdaftar, artinya 61\% bidang tanah yang ada di Indonesia belum diukur dan belum dipetakan oleh Kementerian ATR/BPN. Jika hanya mengandalkan sumber daya manusia dengan status Aparatur Sipil Negara (ASN) sebagai petugas ukur untuk pekerjaan pengukuran batas bidang tanah, maka sangat mustahil pemenuhan target percepatan pendafataran tanah tercapai. Maka untuk itu perlu penambahan petugas ukur dengan status kepegawaian ASN/PNS untuk menyelesaikan pengukuran dan pemetaan seluruh bidang tanah yang belum terdaftar. Dalam kurun waktu 5 tahun akan dibutuhkan 10.686 orang dan kurun waktu to tahun akan dibutuhkan 4.651 orang. Maka untuk itu perlu keterlibatan swasta dalam melaksanakan tugas Kementerian ATR/BPN bidang pengukuran dan pemetaan, privatisasi petugas ukur pertanahan melalui surveyor kadaster berlisensi menjadi salah satu solusi.

Di Indonesia, Surveyor Kadaster Berlisensi (SKB) terdiri atas Surveyor Kadaster (SK) dan Asisten Surveyor Kadaster (ASK). Berdasarkan data dari Direktorat Pengukuran dan Pemetaan Dasar Kemen- terian ATR/BPN tahun 2015 jumlah surveyor kadaster sebanyak 151 orang dan Asisten Surveyor Pertanahan (ASP) sebanyak 2.039 orang. Pada tanggal 19 September 2016, berdasarkan pengumuman dari Direktur Pengukuran dan Pemetaan Dasar Dirjend Infrastruktur Keagrariaan Kementerian ATR/BPN No. 66/PENG/IX/2016 tentang Penetapan Peserta Lulus Ujian Tertulis Surveyor Berlisensi Tahun 2016, surveyor berlisensi yang lulus ujian tulis terdiri atas 145 Surveyor Pertanahan dan 388 Asisten Surveyor Pertanahan. Sehingga jumlah total sampai saat ini Surveyor Berlisensi 2.723 orang yang terdiri atas 296 Surveyor Pertanahan dan 2.427 Asisten Surveyor Pertanahan.

Perkembangan berikutnya mulai bulan Februari sampai dengan Agustus tahun 2017 telah dilakukan ujian untuk memperoleh lisensi bagi calon Surveyor Kadaster Berlisensi di seluruh Indonesia oleh Direktorat Jenderal Infrastruktur Keagrariaan Kementerian ATR/BPN. Dengan ditetapkannya Peraturan Menteri Agraria dan Tata Ruang/Kepala Badan Pertanahan Nasional Nomor 33 Tahun 2016 tentang Surveyor Kadastral Berlisensi kemudian diubah dengan Peraturan Menteri Agraria dan Tata Ruang/ Kepala Badan Pertanahan Nasional Nomor 11 Tahun 2017 tentang Perubahan Peraturan Menteri Agraria dan Tata Ruang/Kepala Badan Pertanahan Nasional Nomor 33 Tahun 2016 tentang Surveyor Kadastral Berlisensi. Maka problem tentang kekurangan petugas ukur untuk melaksanakan dan menjalankan program Percepatan Pendaftaran Tanah Sistematik Lengkap Kementerian ATR/BPN diharapkan terselesaikan.

Jumlah dan distribusi Surveyor Kadastral Berlisensi baik Surveyor Kadastral maupun Asisten Surveyor Kadastral ternyata belum memenuhi harapan Kementerian ATR/BPN, distribusi dan jumlah SK dan ASK yang tidak merata di seluruh provinsi dan kabupaten. Kondisi Surveyor Kadastral Berlisensi pada wilayah kerja Kantor Wilayah Badan Pertanahan Nasional Provinsi Sumatera Utara yaitu 1 (satu) Kantor Jasa Surveyor Kadaster 
Berlisensi Perseorangan (KJSKB) dengan nama Boston Sianturi. Sedangkan Surveyor Kadaster Berlisensi perseorangan sejumlah 6 orang SK dan 130 orang ASK, belum termasuk ASK yang berasal dari lulusan Sekolah Tinggi Pertanahan Nasional saat ini yang sedang melakukan magang kerja di kantor-kantor pertanahan tersebar di seluruh Provinsi Sumatera Utara. Volume pekerjaan seluruh Provinsi Sumatera Utara rata-rata 970o bidang/ bulan, sedangkan target total bidang tanah program PTSL sejumlah 210.oo bidang. Sampai akhir Agustus 2017 telah terukur 54.862 bidang tanah, berarti baru mencapai $26,12 \%$ dari target keseluruhan. Dengan adanya perubahan peraturan tentang Surveyor Kadaster Berlisensi, penerapan Peraturan Menteri Agraria dan Tata Ruang/Kepala Badan Pertanahan Nasional Nomor 11 Tahun 2017 tentang Perubahan Peraturan Menteri Agraria dan Tata Ruang/Kepala Badan Pertanahan Nasional Nomor 33 Tahun 2016 tentang Surveyor Kadastral Berlisensi harusnya sudah mulai diterapkan. Berdasarkan Peraturan tersebut, seorang SK (Surveyor Kadaster) dan ASK (Asisten Surveyor Kadaster) dapat melaksanakan pekerjaan pengukuran dan pemetaan dalam rangka pendaftaran tanah secara perseorangan tidak harus bergabung dengan KJSKB. Dengan adanya perubahan ini diharapkan sebagai mitra Kementerian ATR/BPN dapat membantu dan mempercepat PTSL.

Ternyata dalam kenyataannya implementasi regulasi tentang Surveyor Kadaster Berlisensi tidak mudah, terkait kewenangan Surveyor Kadaster Berlisensi tidak sepenuhnya dapat dilaksanakan dan hasil yang diperoleh tidak sepenuhnya dapat dipercaya khususnya kebenaran, keabsahan, dan ketelitian hasil pekerjaan Surveyor Kadaster Berlisensi. Maka untuk itu tujuan penelitian ini adalah:

1. Mengetahui Implementasi regulasi tentang Surveyor Kadastral Berlisensi di Kantor Wilayah Badan Pertanahan Nasional Provinsi Sumatera Utara.
2. Mengetahui keterbatasan dan kendala dalam pelaksanaan regulasi tentang Surveyor Kadastral Berlisensi di Kantor Wilayah Badan Pertanahan Nasional Provinsi Sumatera Utara. Metode penelitian yang digunakan pada penelitian ini adalah metode penelitian kualitatif dengan mengkombinasikan antar field research (observasi wawancara) dan studi pustaka/desk study (penelusuran data sekunder). Lokasi penelitian wilayah kerja Kantor Wilayah Badan Pertanahan Nasional Provinsi Sumatera Utara yang terdiri atas Kantor Wilayah BPN Provinsi Sumatera Utara dan Kantor Pertanahan: Kota Binjai, Kabupaten Deli Serdang, Kabupaten Karo, Kabupaten PakPak Bharat, Kabupaten Dairi, Kabupaten Serdang Bedagai, Kabupaten Tebing Tinggi, Kabupaten Pematang Siantar, Kabupaten Simalungun, dan Kota Medan.

\section{B. Gambaran Petugas Ukur di Indonesia dan Negara Lain}

\section{Privatisasi Petugas Ukur Pertanahan Negara Lain}

Pengalaman dari beberapa negara di Eropa, Australia dan Selandia Baru, serta Malaysia pekerjaan petugas ukur di bidang pertanahan sudah dilaksanakan oleh pihak swasta. Peran pemerintah hanya membuat regulasi, mengawal regulasi, dan supervisor. Bahka di beberapa negara supervisor profesi Petugas Ukur Pertanahan dilaksanakan oleh organisasi profesi. Petugas ukur pertanahan swasta ini diberikan kewenangan oleh negara untuk melaksanakan fungsi pemerintah di bidang pengukuran dan pemetaan untuk kepentingan kadaster atau pendaftaran tanah. Di Eropa, petugas ukur pertanahan swasta yang menjalankan fungsi pemerintah di bidang survey disebut GeometerEuropas (GE). Geometer-Europas merupakan kegiatan profesional di bidang surveyyang dilakukan oleh individu dengan kualifikasi yang sangat tinggi, tanggung jawab pekerjaan secara pribadi/personal dan akuntabel, serta di bawah otoritas pemerintah. 
Geometer-Europas yang menggantikan fungsi pemerintah di beberapa Negara Eropa, penyebutannya di setiap negara berbeda:

$\begin{array}{ll}\text { France } & \text { :Géomètre Expert Foncier } \\ \text { Austria } & \text { :Ingenieurkonsulent für } \\ & \text { Vermessungswesen }\end{array}$

Switzerland : Patentierter Ingenieur-Geometer

Germany :Öffentlich bestellter Vermessungsingenieur

Belgium :Géomètrejuré

Denmark :Praktiserende Landinspektør.

Petugas Ukur Pertanahan atau Surveyor Pertanahan di Australia dan Selandia Baru disebut dengan Surveyor Berlisensi (Resgitered Surveyor), mereka diatur dalam suatu undang-undang termasuk tentang kualifikasi dan pengalaman profesional. Di Malaysia petugas ukur pertanahan atau surveyor pertanahan disebut dengan Juru Ukur Berlesen, dengan tugas melakukan pengukuran dan pemetaan bidang tanah untuk kadaster. Profesi Surveyor Pertanahan di beberapa negara tersebut di atas dalam melaksanakan fungsi pemerintah dalam kegiatan pengukuran dan pemetaan bidang kadastral merupakan pejabat publik atau pejabat umum. Dalam melaksanakan pekerjaan survey di beberapa negara Eropa, surveyor kadastral bekerja di bawah firma atau badan hukum tertentu. Surveyor Berlisensi di Malaysia dapat bekerja di bawah firma/badan hukum tetapi juga memungkinkan bekerja secara perseorangan.

Pengalaman dari beberapa negara, pembinaan dan pengawasan surveyor berlisensi dilaksanakan oleh organisasi profesi surveyor berlisensi tersebut ataupun oleh suatu departemen yang menangani bidang survei, pengukuran, dan pemetaan di negara tersebut. Di Eropa termasuk Jerman, karena surveyor berlisensi termasuk suatu profesi maka dia bertanggung jawab atas nama dirinya sendiri selaku professional terhadap pekerjaan yang dilakukannya. Surveyor berlisensi di Australia dalam melakukan tugasnya tunduk terhadap peraturan perundang yang berlaku dan organisasi profesi yang membawahi wilayah kerja surveyor berlisensi yaitu Dewan Jendral Surveyor Berlisensi. Dewan Jendral Surveyor Berlisensi ini memiliki tugas antara lain mendaftar ulang lisensi surveyor, melakukan investigasi jika terjadi kesalahan dalam survey dan memberikan koreksinya, serta melakukan pemantauan kinerja surveyor berlisensi dalam suatu audit berkala.

Pengalaman surveyor berlisensi di Semenanjung Malaysia (Malaysia dan Brunei) tidak serta merta seseorang yang memiliki ijasah perguruan tinggi bisa mengikuti ujian untuk memperoleh lisensi. Ada tiga tahap yang harus dilalui yaitu; Tahap I: Orang berartikel, Tahap II: Juru ukur tanah berdaftar, dan Tahap III: Juru ukur berlisensi. Kualifikasi surveyor kadaster swasta atau profesi Geometer-Europas di Eropa yaitu: 1) lulus pendidikan akademik formal/ sarjana, 2) mengikuti pelatihan khusus dan lanjut bidang hukum properti-real estate (pertanahan) dan hukum administrasi selama satu atau dua tahun dan mengikuti ujian akhir untuk tujuan memperoleh gelar profesi, 3) memiliki pengalaman praktis pada jangka waktu tertentu.

Uni Eropa memiliki kewajiban mendistribusikan Geometer ini keseluruh negara Eropa, karena di setiap negara Eropa memiliki standart profesi dan kualifikasi yang berbeda dalam bidang survey kadastral. Kualifikasi dan cara memperoleh lisensi sebagai Surveyor Berlisensi di Australia dan Selandia Baru adalah sebagai berikut: 1) harus sarjana di bidang ilmu spasial, geomatika atau yang sejenis dari perguruan tinggi terkemuka, 2) mengikuti pelatihan dan memiliki pengalaman kerja dari Surveyor Berlisensi yang telah memiliki perjanjian pelaksanaan pelatihan dengan Dewan Jendral Surveyor Berlisensi, 3) mengikuti ujian yang dilaksanakan oleh Dewan Jendral Surveyor Berlisesni pada setiap Negara bagian, 4) calon surveyor berlisensi tersebut diakreditasi oleh Dewan Jendral Surveyor Berlisensi untuk mendapatkan kriteria mahir dalam praktek pengukuran bidang tanah serta berhak memperoleh lisensi untuk melaksanakan tugas 
sebagai Surveyor Berlisensi di bawah register Dewan Jendral Surveyor Berlisensi di setiap wilayah Negara Bagian.

Pengalaman dari beberapa Negara, ternyata proses pelantikan selaku surveyor berlisensi dilaksanakan di bawah naungan organisasi profesi tidak lagi dilakukan di bawah departemen atau instansi pemerintah. Wilayah kerja Surveyor berlisensi di negara Eropa (termasuk Jerman), Australia, Malaysia, dan Brunei adalah satu negara bagian dan masing masing negara bagian tersebut memiliki aturan tersendiri. Kualifikasi pendidikan juru ukur surveyor berlisensi di Malaysia, Brunei, dan Singapura minimal sarjana.

\section{Petugas Ukur Pertanahan di Kementerian Agraria Tata Ruang/Badan Pertanahan Nasional}

Petugas Ukur Kementerian ATR/BPN, seperti yang dimaksud dalam Peraturan Pemerintah Nomor 24 Tahun 1997 tentang Pendaftaran Tanah dan Peraturan Menteri Negara Agraria/Kepala Badan Pertanahan Nasional Nomor 3 Tahun 1997 Ketentuan Pelaksanaan Peraturan Pemerintah Nomor 24 Tahun 1997 Tentang Pendaftaran Tanah untuk pendaftaran tanah secara sistematik disebut Satgas Pengukuran dan pemetaan sedangkan untuk Pendaftaran Tanah secara Sporadik disebut Petugas Pengukuran. Di samping petugas ukuryang merupakan PNS/ASN Kementerian ATR/BPN, kewenangan melakukan pengukuran dan pemetaan dilimpahkan kepada licensed surveyor (termuat dalam penjelasan Peraturan Pemerintah No. 24/ 1997 Pasal 20 ayat 4 dan Peraturan Menteri Negara Agraria/Kepala Badan Pertanahan No. 3 Tahun 1997 Pasal 77 ayat 3, 4, dan 5). Kemudian untuk lebih operasional mengenai licensed surveyor atau surveyor berlisensi diatur oleh Peraturan Menteri Negara Agraria/Kepala BPN No. 2 Tahun 1998 tentang Surveyor Berlisensi dan Keputusan Menteri Negara Agraria/Kepala Badan Pertanahan Nasional Nomor 8 Tahun 1998 tentang Ketentuan Pelak- sanaan Peraturan Menteri Negara Agraria/Kepala Badan Pertanahan Nasional Nomor 2 Tahun 1998 tentang Surveyor Berlisensi.

Pada tahun 2013, kedua peraturan tentang surveyor berlisensi diganti dengan Peraturan Kepala Badan Pertanahan Nasional Republik Indonesia No. 9 Tahun 2013 tentang Surveyor Berlisensi. Dengan berlakunya peraturan-peraturan tersebut, fungsi pemerintah dalam kegiatan survey untuk kegiatan pendaftaran tanah dapat dilakukan oleh Petugas Ukur Pertanahan Swasta atau Surveyor Berlisensi, tetapi dengan kewenangan terbatas. Kemudian pada tahun 2016, untuk mempercepat penyediaan data spasial bidang-bidang tanah Peraturan Kepala Badan Nasional Republik Indonesia No. 9 Tahun 2013 dihapus dan diganti dengan Peraturan Menteri Agraria Dan Tata Ruang/Kepala Badan Pertanahan Nasional Republik Indonesia Nomor 33 Tahun 2016.

Selanjutnya untuk lebih mengoptimalkan sumber daya Surveyor Kadaster Berlisensi dilakukan perubahan terhadap peraturan tersebut dengan dikeluarkan Peraturan Menteri Agraria dan Tata Ruang/Kepala Badan Pertanahan Nasional Republik Indonesia Nomor 11 Tahun 2017 tentang Perubahan atas Peraturan Menteri Agraria dan Tata Ruang/ Kepala Badan Pertanahan Nasional Nomor 33 Tahun 2016 Tentang Surveyor Kadaster Berlisensi. Terdapat perubahan yang sangat signifikan, dibanding peraturan sebelumnya. Dengan berlakunya peraturan menteri ini, surveyor berlisensi dapat menerima permohonan pengukuran dan pemetaan bidang tanah untuk keperluan pendaftaran tanah maupun keperluan pemetaan tematik melalui mekanisme penunjukan dari kantor pertanahan atau secara langsung dari masyarakat. Surveyor Kadaster dan Asisten Surveyor Kadaster tersebut diberi pilihan dalam melaksanakan pekerjaannya yaitu dapat bekerja selaku perseorangan secara personal mandiri atau bergabung dan atau mendirikan badan usaha dapat berupa badan usaha perorangan maupun badan usaha berbentuk persekutuan atau firma yang disebut dengan Kantor Jasa Surveyor 
Kadaster Berlisensi (KJSKB). Badan usaha perorangan disebut KJSKB Perorangan sedangkan badan usaha yang berbentuk persekutuan atau firma dinamakan KJSKB Firma. Selain hasil pekerjaan yang dilaksanakan oleh KJSKB bersifat mengikat dan bertanggung jawab sepenuhnya dengan hasil pekerjaan baik secara administrasi maupun secara hukum. KJSKB, Surveyor Kadaster, dan Asisten Surveyor Kadaster mempunyai wilayah kerja dalam wilayah 1 (satu) provinsi, menteri dapat memberikan kewenangan melebihi wilayah kerja jika dirasa perlu. Kewenangan KJSKB, Surveyor Kadaster, dan Asisten Surveyor Kadaster terkait dengan pekerjaan pendaftaran tanah pertama kali adalah data hasil ukuran lapangan, Gambar Ukur, Peta Bidang Tanah, dan hasil pelayanan atau kegiatan survei dan pemetaan lainnya sesuai dengan ketentuan peraturan perundang-undangan.

\section{Percepatan Pendafataran Tanah Sistematik Lengkap}

Pemerintahan Joko Widodo telah mencanangkan program strategis dalam bidang pertanahan yang salah satunya adalah percepatan pelaksanaan pendafataran tanah. Salah satu metode untuk percepatan pendaftaran tanah adalah melalui strategi pendaftaran tanah sistematis. Kementerian ATR/BPN telah menetapkan Peraturan Menteri Agraria dan Tata Ruang/Kepala Badan Pertanahan Nasional Nomor 28 Tahun 2016 tentang Percepatan Program Nasional Agraria melalui Pendaftaran Tanah Sistematis. Adanya keterbatasan sumber daya manusia dengan kompetensi survei kadastral di Kementerian ATR/BPN menyebabkan percepatan pendafataran tanah menjadi terhambat sehingga perlu keterlibatan tenaga profesional dan industri survei dan pemetaan. Selanjutnya ditetapkan Peraturan Menteri Agraria Dan Tata Ruang/Kepala Badan Pertanahan Nasional Republik Indonesia Nomor 35 Tahun 2016 tentang Percepatan Pelaksanaan Pendaftaran Tanah Sistematis Lengkap. Keterlibatan tenaga profesional dan sumber pem- biayaan di luar anggaran negara yang ada di Kementerian ATR/BPN diakomodir. Beberapa hal yang prinsip secara operasional dalam pendaftaran tanah belum diatur sehingga dilakukan perubahan Peraturan Menteri tersebut dengan Peraturan Menteri Agraria dan Tata Ruang/Kepala Badan Pertanahan Nasional Republik Indonesia Nomor 1 Tahun 2017 tentang Perubahan atas Peraturan Menteri Agraria dan Tata Ruang/Kepala Badan Pertanahan Nasional Nomor 35 Tahun 2016 tentang Percepatan Pelaksanaan Pendaftaran Tanah Sistematis Lengkap.

Pelaksanaan PTSL dengan berpedoman pada Peraturan Menteri Agraria dan Tata Ruang/Kepala Badan Pertanahan Nasional Nomor 35 Tahun 2016 dan Peraturan Menteri Agraria dan Tata Ruang/ Kepala Badan Pertanahan Nasional Nomor 1 Tahun 2017 masih mengalami kendala dan hambatan. Maka untuk itu diterbitkan Peraturan Menteri Agraria dan Tata Ruang/Kepala Badan Pertanahan Nasional Republik Indonesia Nomor 2 Tahun 2017 tentang Percepatan Pendaftaran Tanah Sistematis Lengkap. Dalam pelaksanaan Percepatan PTSLyang menjadi obyek pendaftaran tanah atau obyek PTSL meliputi seluruh bidang tanah tanpa terkecuali, baik bidang tanah yang belum ada hak atas tanahnya maupun bidang tanah hak, baik merupakan tanah asset Pemerintah/Pemerintah Daerah, tanah Badan Usaha Milik Negara/Badan Usaha Milik Daerah, tanah desa, tanah negara, tanah masyarakat hukum adat, kawasan hutan, tanah obyek landreform, tanah transmigrasi, dan bidang tanah lainnya. Petugas pelaksana kegiatan pengukuran dan pemetaan bidang tanah dalam rangka pengumpulan data fisik pada PTSL dilaksanakan oleh panitia ajudikasi dibantu oleh satgas fisik, yang terdiri dari:

1) Petugas Ukur Kementerian Agraria dan Tata Ruang/ Badan Pertanahan Nasional; atau

2) Surveyor Kadaster Berlisensi (SKB); atau

3) Kantor Jasa Surveyor Kadaster Berlisensi (KJSKB); atau 
4) Perusahaan (Badan Hukum Perseroan) di bidang industri survei, pemetaan, dan informasi geospasial.

\section{Surveyor Kadaster Berlisensi di Provinsi} Sumatera Utara dan Target Pendaftaran Tanah Sistematik Lengkap 2017

Sampai dengan bulan Juli tahun 2017 hanya ada satu KJSKB di seluruh Provinsi Sumatera Utara, yaitu KJSKB Perseorangan Boston Sianturi dengan nomor ijin kerja:122/KEP-15.2/V/2017. Berdasarkan hasil ujian Surveyor Kadaster Berlisensi yang telah dilakukan, diluluskan sebanyak 139 Surveyor Kadaster Berlisensi yang terdiri atas 6 Surveyor Kadaster dan 133 Asisten Surveyor Kadaster. Belum ada lagi penambahan pembentukan KJSKB baik KJSKB Perseorangan maupun KJSKB Firma. SKB yang lolos seleksi dan mendapatkan lisensi masih memposisikan dirinya sebagai SKB perorangan. Pada hari Rabu tanggal 19 Juli 2017, seluruh Surveyor Kadaster Berlisensi dengan wilayah kerja Provinsi Sumatera Utara diundang ke Kantor Wilayah Ba- pertanahan kabupaten/kota Provinsi Sumatera Utara. Hal ini terbukti saat penelitian dilaksanakan, 9 dari 10 kantor pertanahan pasti terdapat ASK lulusan Prodi Di PPKSTPNyang sedang melakukan pekerjaan "magang" di kantor-kantor pertanahan kabupaten/kota. Di samping magang, terdapat juga ASK lulusan Di PPK STPN yang menjadi PTT (Pegawai Tidak Tetap) di kantor wilayah BPN dan kantor-kantor pertanahan.

Program Percepatan PTSL untuk Provinsi Sumatera Utara berdasarkan data dari laporan kegiatan PTSL Kanwil BPN Provinsi Sumatera Utara target PTSL tahun 2017 adalah 210.0oo bidang tanah. Distribusi target PTSL setiap kantor pertanahan kabupaten/kota dan penyelesaiannya sampai dengan tanggal 31 Agustus 2017 dapat dilihat pada tabel 1 berikut ini.

Tabel 1. Laporan Perkembangan Kegiatan PTSL Bidang Infrastruktur Pertanahan Kanwil BPN Provinsi Sumatera Utara Per Tanggal 31 Agustus 2017. dan Pertanahan Nasional Provinsi Sumatera Utara untuk mendengarkan arahan Kepala Bidang Infrastruktur Pertanahan tentang Percepatan Pendaftaran Tanah Sistematis Lengkap dan Rencana Distribusi SKB dalam rangka pengukuran PTSL ke Kantor Pertanahan Kabupaten/Kota se Sumatera Utara. Selain 139 SKB ter-

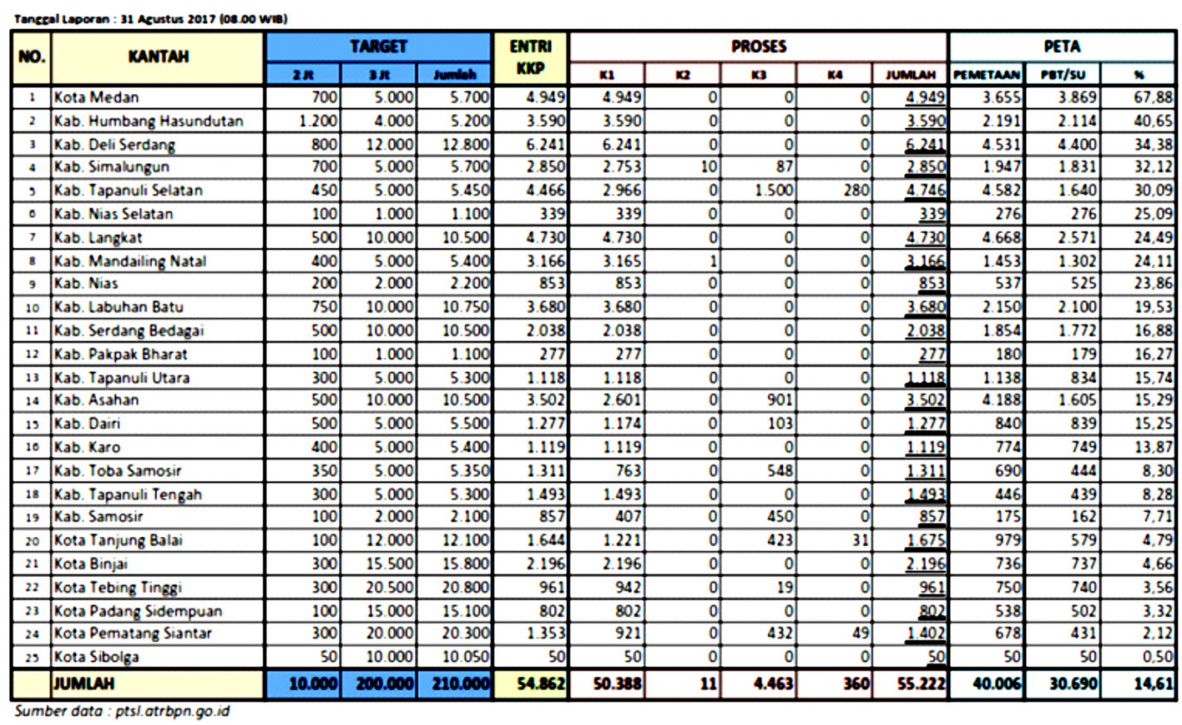

Sampai dengan tanggal 31 Agustus 2017, target yang dicapai dalam kegiatan PTSL sebesar 14,61\% atau 30.690 bidang tanah yang sudah diterbitkan peta bidang dan atau surat ukur. Target semula 10.000 bidang sampai dengan bulan Mei sudah selesai $100 \%$, sedangkan target penambahan 200.ooo baru dimulai setelahnya. Berarti dari bulan Mei sampai dengan akhir Agustus 2017 telah 
menyelesaikan 20.690 bidang. Tahap pengukuran bidang dan sampai pada tahap entri KKP target PTSL secara keseluruhan telah terselesaikan 54.862 bidang atau 26,12\%. Pada penyelesaian total 30.690 bidang sumber daya manusia yang menyelesaikan kegiatan pengumpulan data fisik adalah petugas ukur ASN dan ASK alumni DI PPK STPN yang magang di kantor-kantor pertanahan dan belum melibatkan SKByang baru dilantik pada awal bulan Juli 2017 (karena memang waktunya belum tepat). Pada tanggal 19 Juli 2017 baru dilaksanakan sosialisai PTSL dan pendistribusian SKB di seluruh wilayah Provinsi Sumatera Utara seperti yang telah disebutkan di atas. Hal ini sesuai dengan surat dari Direktorat Jendral Infrastruktur Keagrariaan Nomor 198/S/300-V/2017 tanggal 30 Mei 2017 tentang Optimalisasi Surveyor Kadaster Berlisensi dan GeoKKP yang memerintahkan agar Kantor Wilayah BPN segera mengevaluasi kinerja serta bekerja sama dengan KJSKB, Surveyor Kadaster, dan Asisten Surveyor Kadaster sesuai dengan Peraturan Menteri Negara Agraria dan Tata Ruang/Kepala Badan Pertanahan Nasional Republik Indonesia Nomor 33 Tahun 2016 tentang Surveyor Kadaser Berlisensi dalam pelaksanaan program prioritas Kementerian ATR/BPN. Adapun terkait dengan Peraturan Menteri Agraria dan Tata Ruang/Kepala Badan Pertanahan Nasional Republik Indonesia Nomor 11 Tahun 2017 tentang Perubahan atas Peraturan Menteri Agraria dan Tata Ruang/Kepala Badan Pertanahan Nasional Nomor 33 Tahun 2016 tentang Surveyor Kadaster Berlisensi sampai penelitian dilakukan belum terbit. Akibatnya petunjuk teknis dan sosialisasi belum dilaksanakan, sehingga untuk implementasinya masih menunggu petunjuk teknis tersebut.

\section{Implementasi Regulasi Surveyor Kadaster Berlisensi di Provinsi Sumatera Utara}

Regulasi Surveyor Kadaster Berlisensi yang berlaku saat ini adalah Peraturan Menteri Agraria dan Tata Ruang/Kepala Badan Pertanahan Nasional Republik Indonesia Nomor 11 Tahun 2017 tentang Perubahan atas Peraturan Menteri Agraria dan Tata Ruang/Kepala Badan Pertanahan Nasional Nomor 33 Tahun 2016 tentang Surveyor Kadaster Berlisensi. Meskipun demikian, sebagian peraturan yang terdapat di dalam Peraturan Menteri Agraria dan Tata Ruang/Kepala Badan Pertanahan Nasional Nomor 33 Tahun 2016 tentang Surveyor Kadaster Berlisensi masih berlaku. Perubahan Peraturan Menteri Agraria dan Tata Ruang/Kepala Badan Pertanahan Nasional Nomor 33 Tahun 2016 tentang Surveyor Kadaster Berlisensi meliputi:

1. Kelembagaan SKB (Surveyor Kadaster Berlisensi).

Surveyor Kadaster Berlisensi dapat berbentuk:

a. Perseorangan

b. Badan Usaha berupa Kantor Jasa Surveyor Kadaster Berlisensi yang berbentuk KJSKB Perseorangan dan atau KJSKB Firma.

Tidak ada lagi kewajiban SKB harus berbentuk KJSKB, bahkan perusahaan yang berbentuk badan hukum perseroan yang bergerak di bidang industri survei, pemetaan, dan informasi geospasial dapat memperoleh pekerjaan pengukuran dan pemetaan dalam rangka pendaftaran tanah secara massal atau sistematis. Dengan syarat dalam perusahaan tersebut harus mempunyai Surveyor Kadaster Berlisensi. Bahkan perusahaan ini setelah koordinasi dengan kantor wilayah BPN setempat, dapat melaksanakan kegiatan pengukuran dan pemetaan dalam rangka pendaftaran tanah perorangan dan kelompok masyarakat maupun dalam rangka persiapan pendaftaran tanah sistematik lengkap satu wilayah desa/kelurahan. Hasil survey, pengukuran, dan pemetaan yang berupa gambar ukur ditanda tangani oleh SK atau ASK yang melaksanakan pekerjaan sedangkan Peta Bidang ditanda tangani oleh SK 
yang ditunjuk oleh pimpinan perusahaan badan hukum tersebut.

2. Perpanjangan Lisensi.

Perpanjangan Lisensi tidak lagi secara otomatis diberikan oleh Kementerian ATR/BPN, melainkan ditetapkan terlebih dahulu oleh menteri atau pejabat yang ditunjuk.

3. Persyaratan memperoleh lisensi SK berasal dari ASK.

ASK tidak lagi bisa menjadi SK, meskipun telah bekerja berturut-turut selama 20 tahun, jika ingin menjadi SK tetap harus mengikuti mekanisme dan persyaratan yang telah ditetapkan untuk mendapatkan lisensi sebagai SK.

4. Mekanisme pekerjaan yang dilaksanakan oleh SKB Perseorangan.

SKB Perseorangan hanya dapat memperoleh pekerjaan survei dan pemetaan dalam rangka pendaftaran tanah berdasarkan penugasan dari kepala kantor wilayah BPN, kepala kantor pertanahan, atau pejabat yang ditunjuk dalam mekanisme pekerjaan swakelola oleh kantor wilayah BPN atau kantor pertanahan. Setelah memperoleh pekerjaan, selanjutnya dalam melaksanakan pekerjaan tersebut SKB wajib mendapatkan surat tugas dari kepala kantor wilayah BPN, kepala kantor pertanahan, atau pejabat yang ditunjuk. Hasil pekerjaan disahkan oleh pejabat yang berwenang sesuai perundang-undangan yang berlaku.

5. Hasil Pekerjaan.

Hasil pekerjaan yang dilaksanakan oleh SKB berupa:

a. Data hasil pengukuran di lapangan;

b. Gambar ukur, baik dalam bentuk analog maupun digital yang ditandatangani oleh SKatau ASK yang melaksanakan pekerjaan;

c. Peta Bidang ditandatangani oleh pimpinan/ pimpinan rekan KJSKB atau SK bagi pelaksana pekerjaan Badan Hukum Perseroan atas penunjukkan oleh pimpinan perusahaan tersebut, dan hasil-hasil pelayanan atau kegiatan survei dan pemetaan lainnya sesuai dengan ketentuan peraturan perundang-undangan.

6. Rangkap Jabatan.

Terdapat penambahan larangan yaitu pengurus partai politik dilarang menjadi Surveyor Kadaster Berlisensi.

7. Durasi Waktu Penyelenggaraan Pendidikan Singkat ASK.

Durasi waktu penyelenggaraan pendidikan singkat ASK tidak lagi dibatasi waktunya 6 bulan. Dapat dilihat pada Pasal 31 ayat 1 Peraturan Menteri Negara Agraria dan Tata Ruang/ Kepala Badan Pertanahan Nasional Nomor 11 Tahun 2017, tidak lagi tercantum lamanya pendidikan singkat ASK. Adapun penyelenggara pendidikan tetap dilaksanakan oleh Kementerian ATR/BPN, Pusat Pendidikan dan Pelatian Kementerian ATR/BPN, Sekolah Tinggi Pertanahan Nasional, dan kantor wilayah BPN.

8. Tanggung Jawab Hasil Pekerjaan.

Hasil survei dan pemetaan oleh KJSKB menjadi milik kementerian dan untuk pertanggungjawaban mutlak secara tanggung renteng antara Surveyor Kadaster, Asisten Surveyor Kadaster, dan Pemimpin/Pemimpin Rekan secara bersamaan/mutatis mutandis.

Hasil survey dan pemetaan oleh SKB perorangan menjadi tanggung jawab mutlak pribadi masing-masing Surveyor Kadaster atau Asisten Surveyor Kadaster.

Implementasi dari regulasi SKB di Provinsi Sumatera Utara tidak diterapkan secara murni dan konsekuen, bahkan masih menggunakan Peraturan Kepala Badan Pertanahan Nomor 9 Tahun 2013 tentang Surveyor Kadaster Berlisensi. Hal ini terkait dengan penggunaan tenaga ASK untuk kegiatan pelayanan pengukuran dan pemetaan dalam rangka pendaftaran tanah, yang diharuskan bergabung dengan KJSKB selambat-lambatnya tanggal 1 Oktober 2017 seperti yang diamanatkan dalam Peraturan Menteri Agraria dan Tata Ruang/Kepala 
Badan Pertanahan Nasional Nomor 33 Tahun 2016 tentang Surveyor Kadaster Berlisensi. Hampir semua Kantor Pertanahan memperkerjakan ASK sebagai SKB perorangan. Dan belum mengikuti Peraturan Menteri Agraria dan Tata Ruang/Kepala Badan Pertanahan Nasional Nomor 33 Tahun 2016 tentang Surveyor Kadaster Berlisensi tersebut. Meskipun jika merujuk pada Peraturan Menteri Agraria dan Tata Ruang/Kepala Badan Pertanahan Nasional Nomor 11 Tahun 2017 ASK dan SK yang bekerja selaku perseorangan diperbolehkan. Dalam melaksanakan tugas, SKB tidak diberi surat tugas tersendiri namun masih atas nama petugas ukur ASN. Pekerjaan pengukuran di lapangan dilaksanakan oleh SKB di bawah bimbingan petugas ukur ASN. ASK lulusan Di PPK STPN hampir semuanya melakukan magang di kantorkantor pertanahan bahkan ada yang menjadi PTT. Bahkan di Kantor Pertanahan Kabupaten Karo dalam pekerjaan pengukuran untuk kepentingan pendaftaran tanah, petugas ukur terdiri atas petugas ukur ASN yang dalam pelaksanaan pekerjaan dibantu oleh ASK yang merupakan Alumni Dı PPK STPN, lulusan SMA dengan pelatihan, dan honorer dengan latar belakang pendidikan Sı Geomatika.

ASK yang melaksanakan magang di kantor pertanahan melakukan tugas sebagai pembantu ukur petugas ukur ASN di kantor pertanahan dalam pelayanan pertanahan kepada masyarakat. Dalam melaksanakan pekerjaan tesebut, ASK tidak mendapatkan surat tugas secara khusus, tetapi ikut menandatangani gambar ukur tetapi bukan sebagai yang bertanggung jawab mutlak terhadap pekerjaan telah yang dilaksanakan. Tanggung jawab mutlak terhadap gambar ukur yang berisi catatan dan data ukuran batas-batas bidang tanah merupakan tanggung jawab bersama antara petugas ukur ASN dan ASK. Meskipun begitu surat tugas pengukuran tetap atas nama petugas ukur ASN tidak bersama-sama dengan ASK. Dijumpai juga petugas ukur ASN bersama ASK tetap menandatangi gambarukur meskipun yang melaksanakan pengumpulan data fisik hanya ASK saja.

ASK lulusan DI PPK STPN yang bekerja sebagai PTT melaksanakan tugas seperti administrasi dan pelayanan loket pertanahan. Tetapi ada juga PTT yang merupakan ASK lulusan DI PPK STPN yang juga dibebani pekerjaan pengukuran batas bidang tanah, hanya saja tidak menandatangi gambar ukur. Berdasarkan Peraturan Kepala Badan Pertanahan Nasional Nomor 9 Tahun 2013, Peraturan Menteri Agraria dan Tata Ruang/Kepala Badan Pertanahan Nasional Nomor 33 Tahun 2016 tentang Surveyor Kadaster Berlisensi dan Peraturan Menteri Agraria dan Tata Ruang/Kepala Badan Pertanahan Nasional Nomor 11 Tahun 2017 tentang Perubahan Peraturan Menteri Agraria dan Tata Ruang/Kepala Badan Pertanahan Nasional Nomor 33 Tahun 2016 tentang Surveyor Kadaster Berlisensi dalam melaksanakan pekerjaan pengukuran dalam rangka pendafataran tanah SKB perorangan mendapat surat tugas tersendiri, menandatangani dan bertanggung jawab mutlak secara pribadi atas gambar ukur yang merupakan hasil pekerjaannya sendiri. Tidak ada aturan yang mengatur penandatangan gambar ukur bersama-sama petugas ukur ASN dan ASK. Jadi implementasi regulasi tentang SKB dilaksanakan setengah hati. Sampai saat penelitian dilaksanakan, belum diketahui lisensi yang dimiliki ASK berakhir atau belum. Satu-satunya lisensi SK atas nama Boston Sianturi baru diterbitkan, sehingga belum berakhir masa berlakunya.

\section{E. Keterbatasan dan Kendala Pelaksanaan Regulasi Surveyor Kadaster Berlisensi di Provinsi Sumatera Utara}

Pelaksanaan dan implementasi regulasi tentang SKB tidak bisa diterapkan secara maksimal, dikarenakan terdapat keterbatasan-keterbatasan operasional implementasi regulasi SKB dan kendalakendala yang menghambatnya di lingkungan Kantor Wilayah BPN Provinsi Sumatera Utara. Keterbatasan dan kendala penghambat implementasi regulasi SKB yang ditemukan di Provinsi 
Sumatera Utara sebagai berikut:

1. Keterbatasan

a. Jumlah KJSKB Dan SKB belum Optimal Jumlah KJSKB di Provinsi Sumatera sampai dengan penelitian dilaksanakan baru ada 1 (satu) KJSKB Perseorangan yaitu Kantor Jasa Surveyor Berlisensi Perseorangan Boston Sianturi dengan nomor ijin kerja: 122/KEP-15.2/V/ 2017. Jumlah SKB sampai saat ini adalah 139 SKB yang terdiri atas 6 SK dan 133 ASK. ASK yang merupakan lulusan DI PPK-STPN tersebar di seluruh kantor pertanahan kabupaten/kota Provinsi Sumatera Utara, rata-rata setiap kantor terdapat 2-3 orang yang sedang magang di kantor pertanahan tersebut. Dengan target PTSL 210.0oo bidang tentu jumlah dan keberadaan KJSKB dan SKB belum bisa memenuhi kebutuhan untuk menyelesaikan target PTSL tersebut. Dengan asumsi jumlah ASK lulusan DI PPK-STPN setiap kantah 3 orang seluruh Provinsi Sumatera Utara, maka jumlah total ASK lulusan DI PPK STPN berjumlah 75 orang, sehingga jumlah total SKB yang ada 214 orang. Dengan kemampuan melakukan pengukuran dan pemetaan bidang tanah setiap orang per hari dapat mengukur bidang tanah rata-rata 7 bidang tanah, maka target 200.000 bidang tanah dapat diselesaikan oleh SKB dalam waktu 141 hari atau 4,5 bulan. Jika pengukuran dimulai bulan Agustus, maka akan selesai pertengahan bulan Desember. Dengan selesai pertengahan bulan Desember akan sangat menghambat proses pembukuan hak atas tanah. Hal tersebut dengan catatan seluruh ASK yang ada di kantor pertanahan yang sedang magang kerja dilibatkan dalam proses pengumpulan data fisik. KJSKB memperoleh pekerjaan survei dan pengukuran dalam rangka pendaftaran tanah dan layanan serta kegiatan pertanahan lainnya, melalui:

1) penunjukan dari atau perjanjian kerja dengan masyarakat baik secara langsung atau melalui pihak ketiga; atau

2) mekanisme pengadaan barang dan jasa sesuai dengan ketentuan peraturan perundangundangan.

Dengan hanya ada satu KJSKB Perseorangan, maka pekerjaan-pekerjaan pelayanan pertanahan hanya dapat dilaksanakan oleh satu KJSKB tersebut. Tentu keberadaan KJSKB lainnya dibutuhkan, agar tidak terjadi penumpukan pekerjaan atau beban kerja yang berlebih di satu KJSKB.

b. ASK lulusan DI PPK STPN lebih menyukai sebagai PTT dan "magang"

ASK yang merupakan lulusan DI PPK STPN tersebar di seluruh kantor pertanahan kabupaten/kota di Provinsi Sumatera Utara melakukan pekerjaan "magang" dan ada beberapayang menjadi PTT. Pada saat dilakukan interview/ wawancara dengan mereka diperoleh jawaban yang sama yaitu mereka lebih menginginkan menjadi ASN. Jika hal ini tidak terpenuhi, maka mereka lebih menyukai menjadi PTT atau magang saja. Menjadi PTT menurut mereka merupakan pilihan berikutnya jika tidak diterima menjadi ASN. Karena dengan menjadi PTT, mereka mendapat penghasilan yang jelas, pasti, dan tetap setiap bulannya. Padahal menurut regulasi SKB, SKB tidak boleh merangkap sebagai PTT, akibatnya profesi dan lisensi ASK yang dimilikinya tidak bisa digunakan/tidak berlaku jika melaksanakan pekerjaan pengukuran dan pemetaan untuk kepentingan pendaftaran tanah. Nama mereka tidak boleh dicantumkan dalam surat tugas pengukuran dan ASK tersebut tidak boleh menandatangani gambar ukur. Demikian juga saat magang, ASK menjadi pembantu ukur bukan lagi menjalankan profesi sebagai ASK. Terdapat kegamangan, rasa takut, dan rasa tidak percaya diri dalam menjalankan tugas profesional sebagai ASK. Di samping juga kebijakan dari kantor pertanahan belum memberi peluang kepada 
mereka untuk bekerja secara profesional.

\section{c. Modal Usaha SKB}

Calon SKB setalah menempuh ujian lisensi dan dinyatakan lulus seharusnya sudah siap untuk melaksanakan pekerjaan survei, pengukuran, dan pemetaan untuk pendaftaran tanah. Kenyataan yang terjadi adalah SKB tersebut tidak memiliki modal yang cukup untuk membuat kantor sendiri. SKB harus memiliki kelengkapan kerja seperti komputer, scanner, software pemetaan, perabotan kantor, instrument survey seperti Total Station, Rover GNSS, Teodolit dll. Dengan modal usaha yang minim hal tersebut sulit dipenuhi. Peralatan/instrumen survei merupakan peralatan yang wajib dimiliki oleh SKB, kepemilikan ini dapat diartikan memiliki atau menyewa. Kondisi yang dijumpai tidak setiap personil SKB memiliki modal untuk membeli atau menyewa instrumen survei, maka dengan demikian persyaratan pemilikan peralatan survei dapat menghambat pelaksanaan pekerjaan oleh SKB. Ada lagi kendala yang dihadapi yaitu badan hukum perseroan yang bergerak di bidang industri survei, pemetaan, dan informasi geospasial seperti yang disebutkan dalam Petunjuk Teknis Pengukuran dan Pemetaan Kadastral untuk pengumpulan data fisik PTSL dimana pelaksana oleh pihak ketiga diwajibkan memiliki/menyewa instrument: total station atau rover GNSS CORS/RTK, GPS geodetik, scanner, komputer, dan lain-lain. Maka diperlukan modal yang cukup besar. Sehingga hal ini akan menghambat dalam proses memperoleh pekerjaan survei kadastral. Demikian juga ASK yang merupakan alumni DI PPK STPN akan terkendala modal usaha yang minim ini. Pada akhirnya mereka lebih menyukai bekerja magang dari pada menjadi ASK, karena memang tidak memiliki modal usaha. Jika magang, masih bisa menggunakan fasilitas kantor pertanahan untuk melaksanakan tugas pengukuran dan pemetaan. Maka untuk itu perlu strategi khusus mensikapi hal ini, yaitu dengan cara SKB perorangan bergabung dengan Badan Hukum perseroan yang bergerak di bidang industri survei, pemetaan, dan informasi geospasial yang memiliki modal besar.

2. Kendala

a. Aspek Regulasi

Perkembangan Regulasi SKB dimulai tahun 1998 sampai yang terakhir tahun 2017 dengan dikeluarkan Peraturan Menteri Negara Agraria/ Kepala BPN No. 2 Tahun 1998 tentang Surveyor Berlisensi dan Keputusan Keputusan Menteri Negara Agraria/Kepala Badan Pertanahan Nasional Nomor 8 Tahun 1998 tentang Ketentuan Pelaksanaan Peraturan Menteri Negara Agraria/Kepala Badan Pertanahan Nasional Nomor 2 Tahun 1998 tentang Surveyor Berlisensi. Pada tahun 2013, kedua peraturan tentang surveyor berlisensi diganti dengan Peraturan Kepala Badan Pertanahan Nasional Republik Indonesia Nomor 9 Tahun 2013 tentang Surveyor berlisensi. Kemudian pada tahun 2016, untuk mempercepat penyediaan data spasial bidang-bidang tanah Peraturan Kepala Badan Nasional Republik Indonesia No. 9 Tahun 2013 dihapus dan diganti dengan Peraturan Menteri Agraria Dan Tata Ruang/Kepala Badan Pertanahan Nasional Republik Indonesia Nomor 33 Tahun 2016. Selanjutnya untuk lebih mengoptimalkan sumber daya SKB pada tanggal 17 Juli 2017 dilakukan perubahan terhadap peraturan tersebut dengan dikeluarkan Peraturan Menteri Agraria Dan Tata Ruang/ Kepala Badan Pertanahan Nasional Republik Indonesia Nomor 11 Tahun 2017 tentang Perubahan atas Peraturan Menteri Agraria dan Tata Ruang/Kepala Badan Pertanahan Nasional Nomor 33 Tahun 2016 tentang SKB, namun ternyata implementasinya tidak mudah dilakukan. Pada saat penelitian dilaksanakan, publikasi Peraturan Menteri Agraria dan Tata 
Ruang/Kepala BPN RI Nomor 11 Tahun 2017 belum diterima oleh Kantor Wilayah Badan Pertanahan Nasional Provinsi Sumatera Utara. Berdasarkan informasi dari narasumber Kepala Bidang Infrastruktur Pertanahan dan Kepala Bidang Hukum Pertanahan Kantor Wilayah BPN Provinsi Sumatera Utara, Permen ATR/ BPN RI No. 33 Tahun 2016 belum bisa diterapkan di Provinsi Sumatera Utara secara penuh bahkan dalam implementasi regulasi SKB masih mangacu pada Perkaban No. 9 tahun 2013 karena lebih mudah operasionalisasi Perkaban No. 9 Tahun 2013 dibandingkan Permen ATR/ BPN No. 33 Tahun 2016. Hal ini dapat dicontohkan dari kewajiban SKB membentuk KJSKByang disyaratkan oleh Permen ATR/BPN No. 33 tahun 2016 menjadi hambatan tersendiri karena jumlah KJSKB di Provinsi Sumatera Utara pada waktu itu baru ada satu, yaitu KJSKB Perseorangan Boston Sianturi. Akibatnya banyak ASK yang tidak bisa bergabung dengan KJSKB tersebut. Keharusan SKB perorangan ke dalam KJSKB paling akhir bulan Oktober 2017 menjadi kendala tersediri. Beruntunglah ketentuan ini dihapuskan dengan keluarnya Permen ATR/BPNRI No. 11 Tahun 2017. Sehingga diharapkan nantinya SKB perorangan masih dapat bekerja secara mandiri dalam pekerjaan pengukuran dan pemetaan untuk kepentingan pendaftaran tanah. Dalam regulasi Permen ATR/BPN No. 33 Tahun 2016, masih terdapat kebingungan mekanisme pelimpahan pekerjaan dari kantor wilayah BPN ke KJSKB sehingga sulit dilaksanakan. Demikian juga dalam administrasi pelaksanan pengukuran, sampai tanggal 31 Juli 2017 belum dibuatkan daftar SKB dalam sistem Geo-KKP. Hal ini akan menyulitkan dalam penerbitan surat tugas dan menginput hasil kegiatan pengukuran dan pemetaan yang telah dilaksanakan oleh SKB.

b. Kualitas Kompetensi SKB rendah. Mengingat kebutuhan petugas ukuryang tinggi, jika melalui pengadaan ASN memerlukan waktu yang lama serta harus terdapat dukungan dari pemerintah. Langkahyang mudah dilakukan adalah membuka karier profesional sebagai SKB dengan kualifikasi dan kompetensi SKByang telah ditetapkan dalam Permen ATR/ BPN No. 11 Tahun 2017 dimana untuk Surveyor Kadaster harus:

1) Sarjana strata satu ( $\mathrm{S} 1)$ dengan program studi di bidang survei dan pemetaan;

2) Mantan pegawai kementerian yang telah bekerja berturut-turut 20 tahun yang memiliki keahlian di bidang survey dan pemetaan pertanahan.

Sedangkan ASK harus memiliki pendidikan sekolah menengah kejuruan, diploma satu (D1), atau diploma tiga $\left(D_{3}\right)$ di bidang survey dan pemetaan. Dengan kualifikasi pendidikan tersebut, seseorang dapat mengikuti ujian lisensi untuk mendapatkan lisensi SKB. Tidak ada uji kompetensi atau uji kemampuan teknis dan yuridis secara khusus, sehingga kualitas kompetensi SKB tidak diketahui, akibatnya setelah dinyatakan lulus ujian lisensi ternyata memiliki kompetensi yang rendah. Rendahnya kompetensi diketahui setelah akan melaksanakan pekerjaan, pengetahuan tentang pengukuran dan pemetaan yang rendah sehingga tidak siap secara teknis dalam melaksanakan pengukuran dan pemetaan untuk pendaftaran tanah. Menurut Kepala Bidang Infrastruktur Pertanahan Kanwil BPN Sumatera Utara, kemampuan teknis pengukuran dan pemetaan masih lebih baik ASK (lulusan Di PPK STPN) yang sedang magang. Untuk itu selain ujian lisensi, maka harus juga dilakukan uji kompetensi bagi SKB. Pengetahuan SKB tentang pendaftaran tanah dan tata laksana pendafataran tanah sangat lemah. Pengetahuan hukum pertanahan, khususnya melaksanakan analisis 
dasar penguasaan tanah terkait dengan alas hak permohonan pengukuran untuk pendafataran tanah juga tidak ada. Maka produk hasil pengukuran yang dilaksanakan oleh SKB menjadi sangat rawan sengketa dan konflik pertanahan. Perlu dibentuk standar kompetensi bidang survei kadaster, standar kompetensi bidang survey kadaster dipergunakan untuk mengukur kompeten atau tidak calon SKB.

c. Sikap Kerja Tidak Profesional

Setelah memperoleh lisensi SKB, para SKB tersebut berkoordinasi dengan Kantor Wilayah Badan Pertanahan Nasional Provinsi Sumatera Utara. Kenyataan yang terjadi para SK dan ASK yang telah mendapatkan lisensi tidak segera berkoordinasi dan kembali menekuni pekerjaan sebelumnya. Tujuan mengikuti ujian SKB hanya ingin memperoleh lisensi sebagai SKB saja. Kemudian ada sebagaian besar yang menuntut memperoleh pekerjaan percepatan pendaftaran tanah dengan pembiayaan pengukuran per bidang lebih besar dari pada yang telah ditentukan. ASK tersebut bahkan meminta diperlakukan seperti petugas ukur ASN atau SK. Salah satu indikator kinerja profesional adalah kemampuan kompetensi, seperti yang telah dibahas di atas kemampuan teknis SKB yang telah lulus ujian lisensi ternyata tidak menunjukkan kemampuan teknis yang baik. Masih banyak SKB yang mengalami kebingungan saat mulai melaksanakan kegiatan pengukuran untuk pengambilan data fisik dalam rangka pendaftaran tanah. Berdasarkan pengalaman-pengalaman terdahulu yang melibatkan pihak ketiga dalam proses pengukuran bidang tanah untuk pendaftaran tanah, hasil pekerjaannya banyak yang tidak sesuai dengan kondisi sebenarnya. Penggunaan alat ukur yang tidak sesuai dengan spesifikasi teknis yang digunakan contoh penggunaan GPS Navigasi untuk pengukuran batas bidang tanah pertanian dalam proyek reforma agraria. Akibatnya tingkat kepercayaan terhadap hasil pengukuran yang dilaksanakan oleh SKB menjadi tidak ada/berkurang, akibat dari sikap yang tidak profesional ini.

\section{F. Penutup}

\section{Kesimpulan}

a. Implementasi regulasi tentang SKB di Kantor Wilayah Badan Pertanahan Nasional Provinsi Sumatera Utara belum dapat dilaksanakan secara penuh, bahkan masih ada yang mengikuti regulasi SKB yang sudah dinyatakan tidak berlaku lagi.

b. Dijumpai beberapa keterbatasan antara lain jumlah KJSKB dan SKB. Selain itu, ASK lulusan DI PPK STPN lebih menyukai magang sehingga tidak mau bergabung dengan KJSKB dan modal keuangan yang dimiliki KJSKB/SKB, hal ini merupakan penyebab tidak lancarnya implementasi regulasi SKB di Kantor Wilayah Badan Pertanahan Nasional Provinsi Sumatera Utara.

c. Pelaksanakan regulasi SKB terhambat oleh persyaratan yang ada di dalam regulasi SKB, kualitas kompetensi SKB rendah, serta sikap kerja tidak profesional.

\section{Rekomendasi}

a. Menambah jumlah SKB dengan melaksanakan pendidikan singkat untuk ASK sesuai Peraturan Menteri ATR/BPN No. 11 Tahun 2017 dan SK dengan memberi peluang kepada pensiunan pegawai Kementerian ATR/BPN.

b. Mendorong pembentukan KJSKB dengan memberi kemudahan dan membimbing dalam pengurusan badan usaha baik badan usaha perorangan maupun firma.

c. Meningkatkan profesionalisme SKB dengan memberi syarat harus memiliki sertifikat 
kompetensi informasi geospasial bagi calon peserta ujian untuk memperoleh lisensi SKB.

\section{G. Ucapan Terima Kasih}

Terima kasih kami ucapkan kepada Bapak Bambang Priono, S.H., M.H., Kepala Kantor Wilayah Badan Pertanahan Nasional Provinsi Sumatera Utara dan Bapak Ir. Nandang Agus Taruna, Kepala Bidang Infrastruktur Pertanahan Kantor Wilayah Badan Pertanahan Nasional Provinsi Sumatera Utara yang telah memberi ijin dan memberikan fasilitas selama penelitian berlangsung. Serta Sdr. Jamaludin Mahasari, yang telah memberi ide dan menemani selama penelitian di Provinsi Sumatera Utara.

\section{Daftar Pustaka}

Attorney General's Chambers, 2011, Licensed Land Surveyors Regulations 2011, Federal

Government Gazette, Malaysia.

Europas, G. Geometer Europas. FIG 2006, Munich. FIG 2005. FIG Statement on the Cadastre. OICRF, Waltersingel 1, 7314 NK Apeldoorn, THE

NETHERLANDS: International Office of the Cadastre and Land Registry (OICRF).

Harsono, Budi, 2005, Hukum Agraria Indonesia, Penerbit Dambatan, Edisi Revisi 2005 (Cetakan

kesepuluh), Jakarta.

Paramia, S., Susanto, H. \& Adi, F. N. 2013. Pemberdayaan Surveyor Berlisensi dalam

Rangka Percepatan Pendaftaran Tanah. Forum Ilmiah Tahunan Ikatan Surveyor Indonesia (FIT- ISI) 2013, 2013 STPN Yogyakarta. Yogyakarta.

Pekka Raitenen, -, Definition Of A Surveyor, FIG Publication No. 2. diakses dari

http://www.fig.net/resources/publications/figpub/ pubo2/figpub_2.pdf (tgl. 5 September 2016).

Peter Dale, 1998, Statement of Ethical Principles and Model Code of Professional Conduct, FIG

Publication No. 17, diakses dari http://www.fig.net/ resources/publications/figpub/pubi7/ figpub_17.pdf (tgl. 5 September 2016).
Peter Morgan, Robert Hodgkinson, Enemark, 1999, Quality Assurance in Surveying Education,

FIG Publication No. 19, diakses dari http:// www.fig.net/resources/publications/figpub/ pub19/figpub_19.pdf (tgl. 5 September 2016).

Widianto, T. Penguatan Status Surveyor Berlisensi Menjadi Pejabat Pengukur Bidang Tanah

(PPBT). FIT ISI 2015, 2015 Malang.

\section{Daftar Perundang-undangan}

Peraturan Pemerintah Nomor 24 Tahun 1997 Tentang Pendaftaran Tanah.

Peraturan Menteri Negara Agraria/Kepala Badan Pertanahan Nasional Nomor 3 Tahun 1997 Tentang Ketentuan Pelaksanaan Peraturan Pemerintah Nomor 24 Tahun 1997 Tentang Pendaftaran Tanah

Peraturan Menteri Agraria Tata Ruang/Kepala Badan Pertanahan Nasional Nomor 35 Tahun 2016 tentang Percepatan Pelaksanaan Pendaftaran Tanah Sistematis Lengkap.

Peraturan Menteri Agraria Tata Ruang/Kepala Badan Pertanahan Nasional No. 1 Tahun 2017 Tentang Perubahan Atas Peraturan Menteri Agraria Tata Ruang/Kepala Badan Pertanahan Nasional Nomor 35 Tahun 2016 tentang Percepatan Pelaksanaan Pendaftaran Tanah Sistematis Lengkap

Peraturan Menteri Agraria Tata Ruang/Kepala Badan Pertanahan Nasional Nomor 12 Tahun 2017 tentang Percepatan Pelaksanaan Pendaftaran Tanah Sistematis Lengkap.

Peraturan Menteri Agraria Dan Tata Ruang/Kepala Badan Pertanahan Nasional Republik Indonesia Nomor 33 Tahun 2016 Tentang Surveyor Kadaster Berlisensi.

Peraturan Menteri Agraria Dan Tata Ruang/Kepala Badan Pertanahan Nasional Republik Indonesia Nomor 11 Tahun 2017 Tentang Perubahan Atas Peraturan Menteri Agraria Dan Tata Ruang/Kepala Badan Pertanahan Nasional Nomor 33 Tahun 2016 Tentang Surveyor Kadaster Berlisensi. 